\title{
PRIVATE AND/OR CORPORATE SECURITY: ARE THERE CONCEPTUAL SIMILARITIES AND DIFFERENCES?
}

Review Paper

\begin{tabular}{|l|l|l|}
\hline DOI 10.7251/ZBKEN1901053L & COBISS.RS-ID 8274968 & UDK 334.728:351.759.4/.5 \\
\hline
\end{tabular}

\author{
Velibor Lalić ${ }^{1}$ \\ Faculty of Security Studies, University of Banja Luka \\ Predrag Ćeranić \\ Faculty of Security Studies, University of Banja Luka \\ Milica Sikimić \\ Faculty of Security Studies, University of Banja Luka
}

\begin{abstract}
This paper addresses the theoretical and conceptual determinations of private and corporate security. Based on the literature review, common characteristics and specificities are examined, and the grounds for conceptual similarities and differences are critically re-examined. The key question is whether the two concepts are different or represent the same concept. The typology of corporate security by Lippert et. al. was used as an analytical framework to compare corporate and private security. Each of the five dimensions in the typology is compared and analyzed. First, the findings of Lippert et al. regarding the above typology are presented followed by the typology, that is, the analytical framework used for the analysis of private security. Finally, the comparison of private and corporate security was performed to see in which dimensions of the typology there are overlaps and similarities, and in which differences. In this regard, the basic conclusion is that private security and corporate security are two related concepts with significant common characteristics (Lat. genus proximum) and specificities that distinguish them from each other (Lat. differentia specifica). The results of the comparative analysis indicate that private security and corporate security are related but conceptually different notions.
\end{abstract}

Keywords: private security, corporate security, privatization, corporation.

\footnotetext{
${ }^{1}$ Corresponding author: Velibor Lalic, Assistant Professor, Faculty of Security Studies, University of Banja Luka. E-mail: velibor.lalic@fbn.unibl.org.
} 


\section{INTRODUCTION}

Over the past few decades, we have witnessed social processes, especially in economically developed democratic countries, which have resulted in the expansion of the non-government or the so-called private security sector. Unsteady global social opportunities, the development of neoliberal trends and global economy, the rise in crime rates and fear of crime change the traditional understanding of the state and its roles, including the perception of which entity in society should provide security services. The opinion of the sociologist Max Weber (Weber, 1976) that the state has a monopoly over the use of force has proved to be outdated. Such an approach simply did not withstand the judgement of time, primarily due to the pressure of globalization which changes the political, economic, social and security structure of the modern world (Pečujlić, 2002; Stiglic, 2004). The weakening role of the nation state, the speed of goods and capital movement, high levels of social inequality, the expansion of international organized crime, terrorism, and armed conflicts are just some of the factors creating the social reality of the modern day and a certain security vacuum in the social space filled in by the private security sector. Since then, this sector has experienced a great expansion in practice, and, on the other hand, has attracted a considerable number of scientists from the field of social sciences dealing with the various aspects of this phenomenon. The issue of private security has largely been addressed by criminologists, primarily from the perspective of privatizing duties that have traditionally fallen within the competence of the police. However, studying private security requires a multidisciplinary approach. In addition to criminology, private security is studied in the field of security studies, politics, sociology, penology and law. Everything started with the question as to whether the state has sufficient capacity to protect the interests of citizens and provide them with security. The criminal justice system in developed countries proved ineffective to respond to numerous challenges in crime control.

In this paper, the phenomenon of the "privatization" of security work is explored in the contemporary social context. However, it should be noted that this activity is not exclusively the phenomenon of contemporary societies. In effect, we can follow it from the ancient Rome, through the 18th-century England to the 19th-century United States (Nemeth, 2018). The privatization of security work goes beyond the issue of crime control. In addition to police work, it now includes activities beyond the scope of police work. Among other things, it is about engaging private agencies as a support to military forces in conflict regions across the world, collecting intelligence, managing penitentiary facilities or migrant and asylum centers, or performing a wide range of activities to protect business and company interests. The most common terms found in the scientific literature include private security, industrial security, private security sector, non-government security sector, and corporate security. Specifically, several terms used to denote this field exist in the scientific literature, which 
creates confusion regarding the fundamental question - are they synonyms or are they similar but still different concepts? On the other hand, we can raise the question of whether there is reasonable ground to accept the phrase private security as a generic term encompassing all those related terms.

The first comprehensive study on private security was published in the United States, in 1971, by the RAND Corporation (Kakalik \& Wildhorn, 1971). The topic of private security has been studied for decades, resulting in numerous papers, to name but a few, (Cunningham \& Taylor, 1985; Shearing \& Stenning, 1983; South, 1988; Jones \& Newburn 1998; De Waard, 1999; Abrahamsen \& Williams, 2010), while the interest of scholars in corporate security is considerably less (Walby \& Lippert, 2013: 208). In the regions of former Yugoslavia, private security began to be studied in the early 2000s, first through individual scientific approaches, primarily through master's theses and doctoral dissertations, and later in educational programs which introduced private security as a subject. In fact, the concept of studying private security is closely related to the degree of development of this activity, which, as such, according to some research (Vejnović, Lalić \& Šikman, 2010), is still developing and has not yet been fully formed.

The subject of this paper is an initial analysis of possible conceptual similarities and differences between private and corporate security. It is a methodologically demanding task. First, the theoretical and conceptual determinations of private security are addressed, followed by the possibility of conceptualizing corporate security. Certainly, these are related concepts with significant common characteristics (Lat. genus proximum), but also specificities, which differentiate them from each another (Lat. differentia specificica). This paper starts with the assumption that private security and corporate security are not synonymous, but rather two concepts that have certain common characteristics. The paper analyzes both concepts in the way they are dealt with in the literature, then it looks at common characteristics and specificities, and finally critically re-examines the merits for addressing their conceptual similarities and differences. The purpose of this paper is to reflect on fundamental theoretical and conceptual issues, problems, inconsistencies, in other words, to emphasize the importance of academic debates regarding the conceptual determinations of private and corporate security and identify their possible similarities and differences.

The section following the introductory considerations section addresses the theoretical and conceptual determinations of private and corporate security. After that, the duties pertaining to private and corporate security and their organizational forms of action are discussed followed by a comparative analysis of the concepts of private security and corporate security. Finally, concluding observations are presented. 


\section{THEORETICAL AND CONCEPTUAL DETERMINATIONS OF PRIVATE SECURITY}

In addition to numerous studies dealing with the various aspects of private security, the lack of theoretical research into basic conceptual issues is evident. In the contemporary literature, there is not a generally accepted definition of private security (Kesić, 2009: 33). As a starting point, the question of what constitutes private security and what activities it involves is discussed. Generally, there is a consensus in the literature that security activities are privatized by non-government stakeholders. Specifically, it is about security work which is not performed by government bodies. Under the laws and other regulations, the state has entrusted work either to legal private entities or private individuals. The problem arises in determining the content or the type of work performed within private security. Based on our literature review, the private sector would encompass the following activities: (1) private policing, (2) private detective activity, (3) private military companies (4) private intelligence companies, and (5) private penal institutions.

There are some terminological ambiguities surrounding the concept of private security. This concept originated from the English-speaking countries, and the most frequently used terms include private security, private policing, the industry of private security. Terminological differences themselves indicate that there is no compliance regarding this concept and there are different interpretations. The largest number of papers has been published in the field of criminology, which address the issues of public policing and private policing (Stenning \& Shearing, 1980; Johnston 1991, Loader, 2000; John, 2005). There is a lack of systematic studies dealing with the issue of extent, organizational forms, trends and implications of the functioning of private security. ${ }^{2}$ Criminologists approach the concept of private security from the perspective of policing and its diversification in terms of the entities which carry out these tasks in society. In the criminological literature, the term private security is mainly regarded as a synonym for private policing, although private security, in the content sense, is a much broader concept. Some scholars start with the criterion of personnel employed in that sector. For example, Shearing and Stenning (1981) argue that they are security personnel employed in the private sector, who perform certain security tasks. Van Steden (2007: 17) critically refers to this approach, primarily because security personnel are employed in the private sector and in the public sector and do not provide services only to commercial entities, but also to public institutions, such as governments, universities, and others institution. Sarre and Prenzel (2005) give a broader interpretation than Shearing and Stenning (1981). They argue it is about personnel employed in

\footnotetext{
${ }^{2}$ A study by Ronald van Steden (2007) offers an explicit framework focusing on six factors that have influenced the expansion of private security: the rise in crime and the problem of crime, massive increase in private property, economic reasons, government policies aimed at the cooperation with the private sector/public-private partnership, the overload of police structures, and the professionalization of private security.
} 
the commercial sector on a contract basis or within individual organizations, that they use private or public funds and that a basic component is to perform certain security activities. There are also other scholars (South, 1994) who define private security similarly, that is, as an activity related to the provision of security services on a commercial basis in order to protect persons and property. What these terms have in common is the provision of security services to the market or public institutions, excluding, for example, the traditional security providers such as the police. Within the field of security studies, papers dealing with private security focus on the topic of private military companies (Bruneau, 2011; Duningan, 2011).

Terminological problems occur when English terms are translated into the South Slavic languages . For example, Kesić (2009) translates the English term private security as "privatno obezbeđenje", thus giving the concept a much narrower meaning. He makes a terminological difference between private security sector and "privatno obezbeđenje" and states that "privatno obezbeđenje" represents one of the components of the private security sector. Kesić (2009) points out two basic approaches in defining the private security sector. In the broader sense, the security sector is defined as "a set of organized forms of activity by voluntary and commercially oriented non-government personnel, whose main duty involves countering criminal behavior" (Kesić, 2009: 11)." In the narrow sense, Kesić defines the concept of private security sector as "a set of legally established professional activities outside the competence of government bodies, which are organized to provide certain services for the protection of the property and safety of citizens and collect information (Kesić, 2009: 11-12)." Based on this definition, Kesić determines the following components of the concept of private security: (1) contractual security - activities performed by private companies or by agencies for physical and technical security services provision on a contractual basis, (2) in-house security - activity performed by security services within private companies and enterprises, and (3) private investigative activity.

Although this is a more comprehensive definition than the previous one, it does not include certain security tasks. This is primarily about private military companies, private intelligence companies, and private penitentiaries. These activities are on the rise and have a significant share in the security market. Particularly private military companies are on the rise and their presence is significant in conflict regions across the world (Leander, 2005; Kinsey 2006). Additionally, neoliberal policies and the massive influx of migrants have led to the privatization of migrant and asylum centers in some countries (Menz, 2011). 


\section{THEORETICAL AND CONCEPTUAL DETERMINATIONS \\ OF CORPORATE SECURITY}

In the literature, departments in charge of security matters within the company corporate security are often regarded as corporate security. This is not a new model and it has been present for decades, more precisely, since the beginning of the twentieth century. Robert P. Weiss (2014) gives a historical overview of the initial phases of corporate security development using the example of the Ford Motor Company in the United States. This period was marked by the use of brutal force, intimidation, tyranny, the recruitment of informers from the ranks of workers and other members of the community and business environment. All this was done in order to control and discipline the workers, prevent strikes and rebellion, and increase labor productivity. Weiss (2014: 17) cites the data of the National Labor Relations Board of 1936, when the board had the data of over 200 registered detective agencies with more than 10,000 people engaged in industrial espionage and strike-breaking at their disposal. Companies in the automobile industry spent millions of dollars on these services. Over time, this sector has evolved and gained a considerable reputation in the professional sense.

The number of studies on corporate security is very small compared to the studies dealing with the issue of private security. At this point, some definitions in the existing literature are discussed. In the Manual for Corporate Security Managers, Kovacic and Halibozek (2003: 48) define corporate security as a process protecting the business of companies. They view corporate security as a synonym for business security. Corporate security protects the company's values and assets. According to Kovacic and Halibozek, private security consists of corporate security, which they also call proprietary security, and contract security. What is significant here is that they consider corporate security to be an integral part of the concept of private security. However, the merits of such a claim need to be re-examined. Corporate security functions within the company, and the company's employees are its security personnel. Corporate security performs the duties related to the security of business ranging from asset protection, business intelligence to the development of emergency plans. Kovacic and Halibozek view contract security as the second element of private security, which includes selling security services to other businesses, institutions or private individuals. Kovacic and Halibozek (2003) further state that companies provide these services to gain profits.

Yet, this division by Kovacic and Halibozek (2003) illuminates two important aspects of this problem - organizational differences in the way

56 corporate security and contract security operate. These differences can be called structural differences. Also, there are functional differences because corporate security has the function of protecting the interests of the corporation and is not intended for the market. On the other hand, the function of the so-called contract security is primarily commercial, they sell security services on the market in order to generate profits. However, the definition by Kovacic and 
Halibozek that private security consists of corporate and contract security should be critically re-examined. Corporations and other organizations that have an in-house security service are not necessarily privately held; they may also be publicly held or with mixed ownership. The element of property relations is very important in the theoretical and conceptual definition of both private and corporate security, which the two authors did not take into consideration. This distinction is correctly observed by Walby and Lippert (2014: 2). They argue that the concept of corporate security is often considered a synonym for in-house security and these services are not "purchased" on the basis of a contract. However, in the broadest sense, they define it loosely as security provision that seeks to achieve corporate organizational goals.

According to Walby and Lippert, corporate security is a synonym for industrial security (2014: 2), which refers to a specific sector of the economy. They associate the concept of corporate security to organization and identify overlaps between these terms. In this case, they use the notion of organizational security. In order to be deemed corporate security, it must be connected with a corporate model, regardless of whether it is a private or public organization. Lippert et al. also point to decommodification trends, as a reverse trend from the privatization of the security activities within the competence of the public sector. They investigated the work of the corporate security departments within the local government organization in Canada and concluded that the activities of these departments, rather than the engagement of companies on a contract basis, constitute the decommodification of arrangements concerning security services. On the other hand, it is about the commodification of strategies and technologies, indicating the complexity of this problem (Lippert et al., 2013). Brooks (2012: 2) confirms that corporate security is not only a field of activity in the private sector. He points to the problem of non-compliance with the definition of the concept of corporate security and indicates the need to do so. He regards corporate security as an area of activity in which security services are provided either within the public or private sector for the purpose of protecting business and material goods.

If we take into consideration that the area of operation of corporate security can be both in the public sector and private sector, we must bear in mind that corporations are not the only economic organizations with which the concept of corporate security is associated. ${ }^{3}$ In addition to business entities, they can also be universities, non-governmental organizations, political parties, churches, and so on.

\footnotetext{
${ }^{3}$ In order to approximately determine the content of the concept of corporate security, we need to look at the etymology of the word corporations. In the lexicon of foreign words (Vujaklija, 1986), the word corporation originates from the Latin corporalis - an association of several people having a common interest and endowed by law with the rights and liabilities of a legal entity, a guild, a society, an association. In the sociological sense, a corporation is a social organization and each organization consists of three basic components: people, organizational structure and management, and decision-making mechanisms. In the sociological theory, social organizations (Kukić, 2004) are defined as groups of people organized to achieve certain goals, which are interconnected on the basis of formally established roles and mutual relations, cooperation and organization.
} 


\section{PRIVATE AND CORPORATE SECURITY WORK AND ORGANIZATIONAL FORMS OF ACTIVITY}

This section discusses the activities frequently performed in the context of private and corporate security. Kovacic and Halibozek (2003) define private security as providing security services, conducting investigations or setting up alarm systems and other advanced technological solutions in the area of security. Additionally, companies providing security services on a contract basis can be global companies that provide security risk analysis services in some conflict areas across the world, crisis management, and so on. It is particularly important to consider the activity of private security companies in crisis regions. In most cases, they carry out logistics, operational support to armed forces, training, strategic advice on defense, crime prevention activities, and intelligence activities (Avant, 2012: 21). There are also private intelligence agencies that collect and process data for clients, be it individuals, companies, or governments. The most common method is the method of collecting and processing open-source intelligence. Private intelligence agencies conduct other activities such as satellite recording, electronic surveillance and signal tracking, surveillance and monitoring, conducting psychological and propaganda activities, and cyberwarfare (Mikac, 2007: 91). Regarding private detective activity, as one of the activities in the area of private security - it mainly involves collecting data about business partners and companies, conducting background checks on job applicants, collecting information and evidence related to copyright infringement (Vejnović et al., 2008), conducting the so-called investigation of spouses, that is, proving adultery, finding missing persons, business escort and surveilling children for the purpose of establishing deviant behavior, gathering evidence for a civil or criminal trial, serving judicial summons and other documents, conducting investigations within the company regarding the appropriation of property, the determination of claims for compensation of damages, monitoring the financial situation of certain individuals, and so on. Private penal institutions are also one of the activities that the state has transferred to the jurisdiction of private companies. The trend of introducing private penal institutions is rising primarily in the United States, Great Britain, Australia, South Africa, and in some European countries. The main cause of the creation of private penal institutions is the significant increase of the prison population and the inability of the state to appropriately respond to new needs. The privatization of penal institutions has advantages and disadvantages and opens up numerous ethical issues, such as the issue of "whether the state is allowed to transfer the execution of criminal sanctions to non-government actors and whether it call into question the resocialization of persons at the expense of profits (Kesić, 2009: 98)."

Nalla and Morash (2002: 13) classify corporate security activities into six categories: the security of persons, access controls, asset protection, investigations, risk management and "Others". Brooks (2012) conducted research in Australia and found that corporate security tasks primarily 
pertain to security technologies, such as IT networks, video surveillance, access control, anti-breach systems, risk management, business continuity management, physical security, reputation protection, industrial security. Only into the second category did Brooks classified investigations, fire protection, occupational safety or business intelligence, suggesting that major tasks certainly depend on the characteristics of a society, its economic development and the specific demands of the market.

Lippert et al. (2013: 216) list the types of corporate security work using an example of local government authorities in Canada, which include the installation and monitoring of video surveillance systems, conducting patrols, removing potential nuisance behavior, employee surveillance, conducting investigations, access control, asset protection, event security, personnel security, security penetration testing system, educating employees to become aware of the security culture and follow the corporate security procedures. Furthermore, Lippert et al. (2013) classify corporate security tasks into two categories according to the complexity criterion: (a) physical security encompassing employee protection, access control and asset protection, which, according to Lippert et al., requires a lower level of complexity, and (b) knowledge work, that is, tasks requiring more complex knowledge (investigations and risk management). According to this division, only physical security could be classified as a task of the lower level of complexity, while the remaining tasks require complex knowledge. The classification of corporate security by Lippert et al. needs to be critically re-examined. Physical security may require specialist knowledge, depending on the level of protection of the facility or person being protected. In such cases, a high quality selection of personnel is performed, a high level of training is ensured, and modern technical equipment and IT technologies are used. These types of work require specific skills acquired by training, far more than theoretical knowledge. Bearing this in mind, the division of security work into skills and knowledge would be more appropriate than that of Lippert et al. Based on the above discussion, we may conclude that private or corporate security activities do not fit into the stereotypical thinking that they are low-skilled jobs - they often require a high level of training and expertise.

The above discussion indicates a wide array of duties performed within the concept of corporate security. They can be classified into categories by their nature: (1) physical security, (2) technical security, (3) information security, (4) investigations, (5) consulting, (6) crisis management, and (7) intelligence.

Regarding the organizational forms of activity within private security, it can be agencies for the protection of persons and property, in-house services within private companies, private investigators/detectives or detective offices, security consulting firms, private military companies, private intelligence companies, private penal institutions, migrant and asylum centers.

As far as corporate security is concerned, corporations have special departments for perform corporate security work, and the employees in those departments are the employees of that company. On the other hand, a 
corporation, regardless of whether it has a special corporate security department or not, can hire services on a contract basis from other security service providers on the market to achieve corporate organizational goals.

\section{ANALYSIS OF PRIVATE AND CORPORATE SECURITY CONCEPTS}

Lippert et al. (2013) developed a typology of corporate security, thus contributing to its conceptual determination. The typology comprises five dimensions of corporate security: (1) public or private status, (2) work type, (3) oversight, (4) source, that is, in-house or contarct services, and (5) certification, training and personnel selection. However, further empirical research is needed within a different cultural, economic, and political context in order to assess its epistemological and practical value. The proposed typology was used as an analytical framework for the comparison of corporate and private security. Each of the five dimensions from the typology was compared and analyzed. First, the research findings obtained by Lippert et al. based on the above typology are presented, followed by the typology, that is, the analytical framework used for the analysis of private security. Finally, the comparison of private and corporate security was performed to see in which dimensions of the typology there are overlaps and similarities, and in which differences. Based on such an approach, we can gain a differentiated overview of the conceptual similarities and differences in private and corporate security. Based on the comparative analysis, the following may be concluded:

\section{Public or private status}

The status of agencies or individuals providing contract security services (private security) is always private. Corporations can be publicly or privately held, or a mixed entity. For example, corporate security departments, if we interpret the concept of corporation in a broader sense, are local government bodies, government institutions, large state-owned or mixed-ownership economic systems. In this context, corporate security does not fully meet the requirement to be regarded as private security because there are status-legal differences in terms of public rather than purely private status, or ownership.

\section{Work type}

According to the typology offered by Lippert et al. (2013), corporate 60 security involves a "range" of work practices which they classify, by the level of complexity, into "physical work" and "work requiring more complex knowledge". It all depends on the company itself that is being protected and the level of threats and risks on the one hand, and the readiness of the management to develop a security department within a particular company on the other hand. The tasks of corporate security and private security are of varying levels 
of complexity. Within the two models observed, there is a significant overlap between tasks. This includes physical and technical protection, investigations, crime prevention, crisis management, IT security, intelligence, and so on. There is even a similarity in the type of work regarding the engagement of the services of private military companies engaged in conflict areas. Corporations operating in this environment engage private military companies to perform work which is similar to person protection, escorting convoys, securing business facilities and infrastructure. The difference is that private military companies are engaged to perform combat tasks, while these tasks are generally not performed within corporate security.

\section{Oversight}

The third dimension of the above typology relates to oversight. Thus, the question arises as to which body oversees these activities. There are no significant differences in this segment of typology between private and corporate security. Both have to act in accordance with the law and other regulations implemented by government bodies, starting from fulfilling working conditions, the licensing of personnel, and so on. However, in addition to the government, the oversight of these activities can also be carried out by professional associations, for example, the American Society for Industrial Security (the ASIS) in the United States, or the Chamber of Private Detectives in Slovenia, Hungary, and so on. In a certain way, the market also oversees their activities, as is the case with public oversight when public security is concerned. Since private security is intended for service markets, the market certainly has a significant impact on the operations of entities providing private security services. The literature also lists other unconventional forms of oversight in relation to corporate security, which pertain to the criminal and civil liability of security managers. The same holds true for private security managers (Lippert et al., 2013).

\section{Source}

Some scholars (Kovacicih \& Halibozek, 2003) distinguish between private and corporate security primarily on the basis of the criterion of providing contract security services, which corresponds to private security. Specifically, it is about engaging private agencies to perform security work. Regarding corporate security, it refers to special in-house/insource departments and the workers in those departments are the company's employees. If we start with a broader definition that these represent activities aimed at protecting the company, the company can engage an agency on a contract basis to perform certain security tasks. Therefore, both modalities are possible. The key difference between private and corporate security in this dimension of typology is that private security tasks are always aimed at the market for the purpose of gaining profits. On the other hand, corporate security protects the interests of the company and does not offer its services on the market, but it can buy 
security services in the same market in order to protect the interests of the company in the best possible way.

\section{Certification, training and personnel selection}

According to the literature, the personnel engaged in corporate security activities have higher levels of education and training than the personnel employed in agencies for the protection of persons and facilities, which provide contract security services (Lippert et al., 2013: 214). An example of this is the ASIS which offers professional certifications and training, which is a minimum qualification standard for corporate security managers. Importantly, it often happens that experienced and trained professionals leave state law enforcement agencies to work in the field of corporate security (Nalla \& Morash, 2002) and in the private security sector. Personnel employed in private security agencies are often synonymous with low-paid jobs and poorly trained security personnel, unlike the personnel working in corporate security departments who often attend specialist training courses. In their typology, Lippert et al. emphasize exactly this distinction between corporate security and contract guard security, that is, private security. However, such an opinion should be critically reexamined given that there are various jobs in the context of private security, including those requiring high qualifications and expertise. Such claims are not supported by research findings.

\section{CONCLUSION}

The notions of private security and corporate security are often used as synonyms. The aim of this paper was to analyze possible conceptual similarities and differences between private security and corporate security. Based on the review of the available literature, it may be concluded that there is an evident lack of research into theoretical and conceptual issues related to the concepts analyzed. We may say that, in addition to numerous studies, especially those dealing with private security, there is not a generally accepted theoretical framework for the conceptualization of both private security and corporate security. This paper discussed some theoretical considerations regarding these concepts. We started with the assumption that private security and corporate security are not synonymous and that the two concepts have certain common characteristics. Private security and corporate security are related concepts with significant common characteristics (Lat. genus proximum) as well as specificities that distinguish them from each other (Lat. differentia specifica). In order to confirm or reject this assumption, we compared the two notions. To this end, the typology of corporate security proposed by Lippert et al. (2013) was used as an analytical framework. The typology comprises five dimensions: 1) public or private status, 2) work type, 3) oversight, 4) source, that is, in-house services or contract services, 5) certification, training and personnel selection. These 
five dimensions were used to analyze private security and corporate security. Based on the comparative analysis, we reached the following key conclusions: the differences between private and corporate security lie in the first element (public or private status) and the fourth element (source, that is, in-house services or contract services). We may conclude that corporate security does not fully meet the requirement to be treated as a private security because there are status-legal differences in terms of public rather than purely private status, or ownership. Additionally, private security work is always aimed at the market in order to gain profits, which is not the case with corporate security. Corporate security protects the interests of the company and does not offer its services on the market, but it can purchase security services in the same market in order to protect the interests of the company in the best possible manner. Corporate security is always connected with corporate identity, being its specific feature that does not necessarily have to be a feature of private security. In other dimensions of security, there are significant overlaps in the typology and there are no significant differences.

Based on the comparative analysis, it may be concluded that private security and corporate security are related but conceptually different concepts. The differences identified between private security and corporate security are significant and, consequently, the concepts analyzed cannot be observed in the same manner.

\section{REFERENCES}

Abrahamsen, R., \& Williams, M. C. (2010). Security beyond the state: Private security in international politics. New York. Cambridge University Press.

Avant, D. (2012). Mercenaries. The Wiley-Blackwell Encyclopedia of Globalization.

Brooks, D. J. (2012). Corporate Security: Using knowledge construction to define a practising body of knowledge. Asian Journal of Criminology, 8(2), 1-13

Bruneau, T. (2011): Patriots for Profit - Contractors and the Military in U.S. National Security; Stanford. Stanford University Press.

Cunningham, W. C., \& Taylor, T. H. (1985). Private security and police in America: The Hallcrest report. Portland, OR: Chancellor Press.

De Waard, J. (1999). The private security industry in international perspective. European Journal on Criminal Policy and Research, 7(2), 143-174.

Duningan, M. (2011): Victory for Hire - Private Security Companies' Impact on Military Effectiveness; Stanford. Stanford University Press.

Halibozek, E., \& Kovacich, G. L. (2003). The manager's handbook for corporate security: establishing and managing a successful assets protection program. Butterworth-Heinemann. 
John E.E. (2005): Conceptualizing the Private Police. Utah Law Rewiew, 2, 573-617.

Johnston L. (1991). Privatisation and police function: from "new police" to "new policing" -in. Reiner R. and Cross M. (ed.): Beyond Law Order: Criminal Justice Policy and Politics in the 1990s, Basingstoke, Macmillian, pp. 18-40.

Jones, T., \& Newburn, T. (1998). Private security and public policing. Clarendon Press.

Kakalik, J. S., \& Wildhorn, S. (1971). The Private Police Industry: Findings and Recommendationes (5 volume Rand report for the US Department of Justice), Santa Monica, Rand Corporation.

Кесић, 3. (2009). Приватни сектор у контроли криминалитета. Београд: Досије Студио.

Kinsey, C. (2006). Corporate soldiers and international security: The rise of private military companies. Routledge.

Кукић, С. (2004). Социологија: теорије друштвене структуре. Sarajevo Publishing.

Leander, A. (2005). The power to construct international security: On the significance of private military companies. Millennium, 33(3), 803-825.

Lippert, R. K., Walby, K., \& Steckle, R. (2013). Multiplicities of corporate security: Identifying emerging types, trends and issues. Security Journal, 26(3), 206-221.

Loader I. (2000). Plural policing and democratic governance. Social and Legal Studies, 9, 323-345.

Menz, G. (2011). Neo-liberalism, privatization and the outsourcing of migration management: a five-country comparison. Competition \& Change, 15(2), 116-135.

Микац, Р. (2007). Феномен „приватних војних организација”: незаобилазне компоненте у сукобима 21. стољећа. Полемос: часопис за интердисциплинарна истраживања рата и мира, 10(20), 85-107.

Nalla, M.K. and Morash, M.A. (2002). Assessing the scope of corporate security: Common practices and relationships with other business functions. Security Journal 15(3), 7-19.

Nemeth, C. P. (2018). Private security: An introduction to Principles and Practice. CRC Press Taylor \& Francis Group.

64 Печујлић, М. (2002). Глобализација: два лика света. Београд. Гутенбергова галаксија.

Sarre, R., \& Prenzler, T. (2005). The law of private security in Australia. Pyrmont, Thomson Lawbook. 
Shearing, C. D., \& Stenning, P. C. (1981). Modern private security: its growth and implications. Crime and sustice, 3, 193-245.

Shearing, C. D., \& Stenning, P. C. (1983). Private security: implications for social control. Social problems, 30(5), 493-506.

South N. (1994). Privatizing policing in the European Market. European Sociological Rewiew, 10(3), 219-231.

South, N. (1988). Policing for profit: The private security sector. Sage.

Stenning P. C. and Shearing C. D. (1980). The quiet revolution - The nature, development and general legal implications of private policing in Canada, Criminal Law Quarterly, 22, 220-248

Stiglic, E. J. (2004). Proturečnosti globalizacije. Beograd: SBM-h.

Van Steden, R. (2007). Privatizing Policing - Describing and Explaining the Growth of Private Security. Den Haag: BJu Legal Publishers.

Walby, K., \& Lippert, R. K. (2014). Introduction: Governing Every Person, Place, and Thing-Critical Studies of Corporate Security. In Corporate Security in the 21st Century (pp. 1-13). London: Palgrave Macmillan.

Weiss, R. P. (2014). Corporate security at Ford Motor Company: from the great war to the cold war. In Corporate Security in the 21st Century (pp. 17-38). London: Palgrave Macmillan.

Вебер, М. (1976). Привреда и друштво. Београд: Просвета.

Вејновић, Д., Тривуновић, Ј., Матијевић, М., Ђокић, П., Вртовец, З., Лалић, В., Шикман, М., Перко, Ј., Ђукић С. (2008). Детективска дјелатност теоријски и практични аспекти по стандардима Европске уније. Бања Лука: Дефендологија центар за безбједносна, социолошка и криминолошка истраживања.

Vejnović, D., Lalić, V., Šikman, M. (2010). Private Security in Bosnia and Herzegovina. In: Cordner, G., Cordner, A., Das, D. (Eds). Urbanization, Policing, and Security - Global Perspectives. (389-402). New York: Taylor \& Francis Group,

Вујаклија, М. (1986). Лексикон страних речи и израза. Београд: БИГз.

Paper received on: 01. 03. 2019.

Paper accepted for publishing on: 29. 03. 2019. 


\section{ПРИВАТНА И/ИЛИ КОРПОРАТИВНА БЕЗБЈЕДНОСТ Да ли постоје концептуалне сличности и разлике?}

Прегледни научни рад

\begin{tabular}{|l|l|l|}
\hline DOI 10.7251/ZBK1901055L & COBISS.RS-ID 8273176 & УДК 334.728:351.759.4/.5 \\
\hline
\end{tabular}

Велибор Лалић ${ }^{1}$

Факултет безбједносних наука, Универзитет у Бањој Луци

Предраг Ћеранић

Факултет безбједносних наука, Универзитет у Бањој Луци

Милица Сикимић

Факултет безбједносних наука, Универзитет у Бањој Луци

Апстракт: У раду се анализирају теоријско-концептуална одређења приватне и корпоративне безбједности. На основу прегледа литературе сагледавају се заједничке карактеристике и специфичности, те критички преиспитује основаност третирања њихових концептуалних сличности и различитости. Кључно питање је да ли оне (сличности и разлике) постоје или се ради о једном те истом концепту. Типологија корпоративне безбједности Lippert-a и сарадника кориштена је као аналитички оквир за компарацију корпоративне и приватне безбједности. Свака од пет димензија из типологије упоређивана је и анализирана. Прво су приказани резултати истраживања Lippert-a и сарадника по наведеној типологији, затим је типологија, односно тај аналитички оквир кориштен за анализу приватне безбједности. На кају је извршено упоређивање приватне и корпоративне безбједности како би се сагледало у којим димензијама типологије постоје преклапања и сличности, а у којима разлике. У том смислу основни закључак је да приватна безбједност и корпоративна безбједност су сродни појмови који имају значајне заједничке карактеристике (lat. genus proximum), али и специфичности што их чине различитим једно од другог (lat. differentia specifica). На основу компаративне анализе може се закључити да приватна безбједност и корпоративна безбједност јесу сродни али су и концептуално различити појмови.

Кључне ријечи: Приватна безбједност, корпоративна безбједност, приватизација, корпорација.

\footnotetext{
${ }^{1}$ Аутор за коресподенцију: др Велибор Лалић, доцент на Факултету безбједносних наука. E-mail: velibor.lalic@fbn.unibl.org
} 


\section{УВОД}

Посљедњих неколико деценија свједоци смо друштвених процеса, посеб̆о у економски развијеним демократским државама, који су резултирали експанзијом недржавног или тзв. приватног сектора безбједности. Промјеном глобалних друштвених прилика, развојем неолибералних трендова и глобалне економије, порастом стопе криминалитета и страха од истог, мијењају се традиционална поимања државе и њене улоге укључујући и схватања ко у друштву може да пружа услуге безбједности. Схватање социолога Макса Вебера (Вебер, 1976) да држава има монопол над примјеном силе показало се превазићеним. Такав приступ једноставно није издржао суд времена, првенствено под притиском глобализације која мијења политичку, економску, социјалну и безбједносну структуру савременог свијета (Pečujlić, 2002; Stiglic, 2004). Слабљење улоге националне државе, брзина кретања робе и капитала, велике друштвене неједнакости, експанзија међународног организованог криминала, тероризам, оружани сукоби - само су неки од чинилаца који креирају друштвену стварност данашњице и стварају одређени безбједносни вакуум у друштвеном простору који попуњава приватни сектор безбједности. Од тада до данас овај сектор у пракси доживио је велику екпанзију, и са друге стране, привукао је значајан број научника из области друштвених наука који се баве различитим аспектима овог феномена. Питањима приватне безбједности највише су се бавили криминолози, првенствено из преспективе приватизовања послова који су традиционално припадали полицији. Међутим, изучавање приватне безбједности захтијева мултидисциплинарни приступ. Поред криминологије приватна безбједност предмет је изучавања студија безбједности, политикологије, социологије, пенологије и права. Све је кренуло са питањем да ли држава има довољан капацитет да заштити интересе грађана и да им пружи безбједност. Систем кривичног правосуђа у развијеним земљама показао се неефикасним да одговори на бројне изазове у контроли криминалитета.

У овом раду феномен „приватизовања“ послова безбједности посматра се у савременом друштвеном контексту. Међутим, напомињемо да ова дјелатност није искључиво феномен савремених друштава већ да их можемо пратити још у старом Риму, затим у Енглеској у 18. вијеку и у Сједињеним Америчким Државама у 19. вијеку (Nemeth, 2018). Приватизовање послова безбједности превазилази питања контроле криминалитета. Поред полицијских послова они данас обухватају послове који су ван оквира полицијске дјелатности. Ријеч је, између осталог, о ангажовању приватних агенција у конфликтним регионима у свијету као подршка војним снагама, затим вршење обавјештајних послова, управљање казненим установама, мигрантским и азилантским центрима или је ријеч о широком спектру дјеловања у циљу заштите пословања и интереса компанија. Најчешћи термини који се могу наћи у литератури су приватна безбједност, индустријска безбједност, приватни сектор безбједности, недржавни сектор безбједности, и на крају, 
говори се о корпоративној безбједности. У литератури, дакле, постоји више термина за ову област што уноси нејасноће у вези са основним питањем, да ли је ријеч о синонимима или се ради о сличним, али ипак садржајно различитим појмовима? Са друге стране можемо поставити питање да ли је основано прихватити синтагму приватна безбједност као генерички појам који обухвата све те сродне појмове?

Прва обухватнија студија о приватној безбједности објављена је 1971. године у САД од стране RAND корпорације (Kakalik \& Wildhorn, 1971). Teматика приватне безбједности се изучава деценијама о чему постоји велики број радова, да наведемо само неке (Cunningham \& Taylor, 1985; Shearing \& Stenning, 1983; South, 1988; Jones \& Newburn 1998; De Waard, 1999; Abrahamsen \& Williams, 2010) док, када је ријеч о корпоративној безбједности, интересовање истраживача је знатно мање (Walby \& Lippert, 2013: 208). Приватна безбједност на просторима бивше Југославије почела је да се изучава од почетка 2000-тих година, прво путем индивидуалних научних приступа, прије свега кроз израде магистарских и докторских радова, а касније и кроз наставно-научну дјелатност увођењем наставног предмета Приватна безбједност. Заправо, концепт изучавања приватне безбједности код нас је уско повезан са степеном развоја ове дјелатности, који је као такав, према неким истраживањима (Вејновић, Лалић \& Шикман, 2010), на почетку и у развоју, те још није у потпуности формиран.

Предмет овог рада јесте иницијална анализа евентуалних концептуалних сличности и разлика између приватне и корпоративне безбједности. Овдје се ради о методолошки захтјевном задатку. Прво морамо сагледати која су теоријско-концептуална одређења приватне безбједности, након чега слиједи могућност концептуализације корпоративне безбједности. Свакако је ријеч о сродним појмовима који имају значајне заједничке карактеристике (lat. genus proximum), али и специфичности, што их чине различитим једно од другог (lat. differentia specifica). У раду полазимо од претпоставке да приватна безбједност и корпоративна безбједност нису синоними већ је ријеч о два концепта који имају одређене заједничке карактериситике. У раду се анализирају оба концепта на начин како се они третирају у литератури и након тога се сагледавају заједничке карактеристике и специфичности, те критички преиспитује основаност третирања њихових концептуалних сличности и различитости. То је управо циљ овог рада - да се да осврт на основна теоријско-концептуална питања, проблеме, недоречености, односно да се истакне значај академске расправе у вези са концептуалним одређењима приватне безбједности и корпоративне безбједности, те да се укаже на њихове евентуалне сличности и разлике.

У дијелу рада који слиједи, након уводних разматрања, обрађујемо теоријско-концептуална одређења приватне и корпоративне безбједности. Затим ћемо обрадити сегмент рада који се односи на послове приватне безбједности и корпоративне безбједности те њихове организационе облике дјеловања. Након тога слиједи компаративна анализа концепта приватне 
и концепта корпоративне безбједности. На самом крају рада изнијећемо закључна разматрања.

\section{ТЕОРИЈСКО-КОНЦЕПТУАЛНА ОДРЕЪЕЊА ПРИВАТНЕ БЕЗБЈЕДНОСТИ}

Поред бројних радова који се баве различитим аспектима приватне безбједности евидентан је недостатак теоријских истраживања о основним концептуалним питањима. У савременој литератури не постоји универзална дефиниција приватне безбједности (Кесић, 2009: 33). Полазно питање је шта је то приватна безбједност и које све дјелатности обухвата. Генерално у литератури постоји консензус да је ријеч о приватизовању послова безбједности од стране недржавних субјеката. Дакле, ријеч је о пословима безбједности које не врше државни органи. Те послове, на основу закона и других прописа, држава је повјерила или правним лицима у приватном власништву или физичким лицима. Проблем настаје око одређивања садржаја, односно врсте послова који се обављају у оквиру приватне безбједности. Начелно, прегледом литературе приватни сектор би обухватио сљедеће дјелатности: 1) приватно полицијско дјеловање (engl. private policing) 2) приватну детективску дјелатност 4) приватне војне компаније 5) приватне обавјештајне компаније 6) приватне казнене установе.

Око појма приватна безбједност присутне су терминолошке нејасноће. Овај концепт је настао на енглеском говорном подручју и најчешће су у употреби синтагме engl. private security, private policing, industry of private

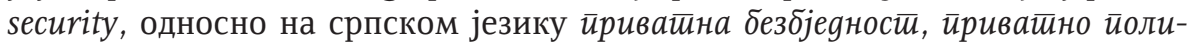

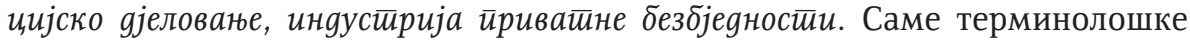
различитости указују да у вези са овим концептом не постоји усаглашеност и да су присутна различита тумачења. Највећи број радова је из области криминологије који третирају тематику односа јавног и приватног полицијског дјеловања (engl. public policing, private policing) (Stenning \& Shearing, 1980; Johnston 1991, Loader, 2000; John, 2005). У литератури је присутан недостатак систематских студија које се баве питањем обима, организационих облика, трендова и импликација дјеловања приватне безбједности. ${ }^{2}$ Криминолози појму приватне безбједности прилазе из перспективе полицијског дјеловања и његове диверзификације у смислу субјеката који те послове обављају у друштву. У криминолошкој литератури углавном приватна безбједност (engl. private security) се сматра синонимом за приватно полицијско дјеловање (engl. private policing) иако је приватна безбједност у садржајном

\footnotetext{
2 Једна од таквих студија потиче од Ronada van Steden-a (2007) који нуди експланаторни оквир фокусирајући се на шест чинилаца који су утицали на експанзију привате безбједности: пораст криминалитета и проблем који се односи на криминалитет, масовни пораст приватне имовине, економски разлози, владине политике усмјерене ка сарадњи са приватним сектором/ јавно - приватно партнерство, преоптерећеност полицијских структура, професионализација приватне безбједности.
} 
смислу много шири појам. Поједни аутори полазе од критеријума особља које је запослено у том сектору. Тако на примјер Shearing i Stenning (1981) наводе да је ријеч о радницима обезбјеђења, који су запослени у приватном сектору и који обављају одређене послове безбједности. Van Steden (2007: 17) критички се односи према оваквом приступу првенствено због чињенице да радници обезбјеђења нису само запослени у приватном већ и јавном сектору, и да не пружају услуге само за комерцијалне субјекте већ и за јавне институције, попут влада, универзитета и других институција. Sarre i Prenzelr (2005) дају шире тумачење у односу на Shearing и Stenning (1981). Они сматрају да је ријеч о особљу запосленом у комерцијалном сектору по основу уговора или су запослени у оквиру појединих организација, да користе приватне или јавне фондове и да је основна компонента да обављају одређене послове безбједности. Ту су и други аутори (South, 1994) који приватну безбједност дефинишу слично, тј. да се ова дјелатност односи на пружање услуга безбједности на комерцијалној основи, како би се заштитила лица и имовина. Оно што је заједничко наведеним одређењима јесте да је ријеч о пружању услуга безбједности било за тржиште или за јавне институције а које искључују, да кажемо традиционалне провајдере безбједности, првенствено полицију. У оквиру студија безбједности радови који се баве приватном безбједношћу фокусирају се на тематику приватних војних компанија (Bruneau, 2011; Duningan, 2011).

Терминолошки проблеми јављају се када се појмови настали у енглеском језику преводе на језике јужнословенских народа. Тако рецимо Кесић (2009) engl. private security преводи као приватно обезбјеђење и тиме појму даје знатно уже значење. Он прави терминолошку разлику између приватног сектора безбједности и приватног обезбјеђења и наводи да је приватно обезбјеђење једна од компоненти приватног сектора безбједности. Овај аутор (Кесић, 2009) указује на два основна приступа у дефинисању приватног сектора безбједности. Шире одређење сектор безбједности дефинише као „скуп организованих облика дјеловања добровољног и комерцијално усмереног недржавног особља, чије примарне дјелатности укључују супротстављање криминалном понашању (Кесић, 2009: 11)."У ужем смислу под појмом приватни сектор безбједности овај аутор дефинише на сљедећи начин: „скуп правно утемељених делатности, професионалног типа, ван оквира надлежности државних органа, које су организоване ради пружања одређених услуга заштите личне и имовинске сигурности грађана и прикупљање информација по наруџби (Кесић, 2009: 11-12)."На основу ове дефиниције Кесић одређује компоненте појма приватне безбједности а то су: 1) уговорно обезбјеђење - дјелатности приватних предузећа или агенција за пружање услуга физичко-техничког обезбјеђења на уговорној основи, 2) унутрашње (сопствено) обезбјеђење - дјелатност служби за обезбјеђење унутар приватних компанија и предузећа и 3) приватна истражитељска дјелатност.

Иако се ради о обухватнијој дефиницији у односу на претходне она не обухвата одређене послове безбједности. Првенствено је ту ријеч о при- 
ватним војним компанијама, приватним обавјештајним компанијама, те приватним казненим установама. Ове дјелатности су у порасту и заузимају запажен удио на тржишту послова безбједности. Посебно су приватне војне компаније у порасту и њихово присуство је значајно у конфликтним регионима у свијету (Leander, 2005; Kinsey 2006). Поред тога, неолибералне политике и масован прилив мигранта довели су до приватизовања мигрантских и азилантских центара у појединим земљама (Menz, 2011).

\section{ТЕОРИЈСКО-КОНЦЕПТУАЛНА ОДРЕБЕЊА КОРПОРАТИВНЕ БЕЗБЈЕДНОСТИ}

У литератури под корпоративном безбједношћу најчешће се сматрају одјељења задужена за послове безбједности у оквиру компаније. Овакав модел није ништа ново, он је присутан већ деценијама, тачније, већ од почетка двадесетог вијека. Robert P. Weiss (Weiss, 2014) даје историјски осврт на почетне фазе развоја корпоративне безбједности на примјеру фабрике аутомобила Форд у Сједињеним Америчким Државама. Овај период је обиљежила употреба бруталне силе, застрашивања, тиранија, регрутовање доушника из редова радника и других чланова заједнице и пословног окружења. Све је то вршено у циљу контроле и дисциплиновања радника, спречавања штрајкова и побуна те повећања продуктивности рада. Weiss (Weiss, 2014: 17) наводи податке Националног одбора за односе са радницима (engl. US. A National Labor Relations Board) из 1936. године, да је тај одбор располагао подацима преко 200 регистованих детективских агенција са више од 10.000 људи ангажованих на пословима индустријске шпијунаже и сламања штајкова. Послодавци из ауто-индустрије трошили су милионе долара за те услуге. Временом овај сектор је еволуирао и стекао велику репутацију у професионалном смислу.

Литература из ове области врло је ограничена у односу на радове који третирају тематику приватне безбједности. Сада ћемо сагледати нека одређења из постојеће литературе. Kovacich i Halibozek (Kovacich \& Halibozek, 2003: 48) у Приручнику за менаџере за корпоративну безбједност под корпоративном безбједношћу сматрају процес којим се штити пословање привредних субјеката. За њих је корпоративна безбједност синоним за безбједност пословања (engl. business security). Корпоративна безбједност штити вриједности и имовину компаније. Ова два аутора сматрају да се приватна безбједност састоји из два дијела. Прво је ријеч о корпоративној безбједности коју још називају engl. proprietary security што би у српском језику најближе значило обезбјеђење имовине. Други елемент engl. contract security, или обезбјеђење на основу уговора. Оно што је овдје значајно јесте да они сматрају корпоративну безбједност саставним дијелом концепта приватне безбједности. Међутим, основаност такве тврдње је потребно преиспитати. Корпоративна безбједност функционише у оквиру компаније и 
особље запослено на пословима безбједности су радници компаније. Корпоративна безбједност обавља све послове који се тичу безбједности пословања од зашите имовине, обавештајног рада у вези са пословањем до израде планова за ванредне ситуације. Безбједност по уговору (engl. contract security) je други елемент приватне безбједности по схватању ова два аутора. Ради се по продаји услуга безбједности другим привредним субјектима, институцијама или приватним особама. Kovacich i Halibozek (2003) даље наводе да те услуге компаније пружају ради стварања профита.

Мада ова подјела по Kovacich-u i Halibozek-u (2003) освјетљава два битна аспекта овог проблема - то су организационе разлике у начину дјеловања корпоративне и безбједности по уговору. Те разлике можемо назвати структуралним разликама. Затим, ту су функционалне разлике јер корпоративна безбједност има функцију заштите интереса корпорације и није намијењена тржишту. Са друге стране функција тзв. безбједности по уговору је примарно комерцијална, они продају услуге безбједности на тржишту у циљу стварања профита. Међутим, одређење Kovacicih-a и Halibozek-a да се приватна безбједност састоји од корпоративне и безбједности по уговору потребно је критички преиспитати. Корпорације и друге организације које имају унутрашњу службу безбједности нужно не морају бити у приватном већ и јавном или мјешовитом власништву. Елемент својинских односа је врло битан у теоријско-концептуалном одређењу и приватне и корпоративне безбједности, а то ова два аутора нису имали у виду. Управо ту дистинкцију правилно уочавају Kevin Walby i Randy Lippert (Walby \& Lippert, 2014: 2). Они наводе да се појам корпоративне безбједности често сматра синонимом за одјељења у оквиру компанија (engl. in-house security), да те услуге нису „купљене“ на основу уговора. Међутим, у најширем смислу, они сматрају да је корпоративна безбједност обезбјеђивање услуга безбједности у сврху остваривања корпоративних циљева.

Walby и Lippert појмом корпоративна безбједност сматрају синонимом за индустријску безбједност (Walby \& Lippert, 2014: 2) која се односи на специфичан сектор привреде. Појам корпоративне безбједности доводе у везу са организацијом и наводе да је присутно терминолошко преклапање појмова. У овом случају они употребљавају појам оріанизациона безбјеgносй. Да би се радило о корпоративној безбједности, она мора бити везана за корпоративни модел, без обзира да ли је ријеч о приватној или јавној организацији. Lippert и сарадници указују и на трендове gекомоgификаиије, као обрнути тренд од приватизације послова безбједности из надлежности јавног сектора. Они су истраживали рад одјељења корпоративне безбједности у оквиру организација локалне управе у Канади и закључили, између осталог, да дјеловање тих одјељења, а не ангажовање компанија по уговору, представља декомодификацију аранжмана када су услуге безбједности у питању. Са друге стране, ради се о комодификацији стратегија и технологија, што све указује на комплексност ове проблематике (Lippert et. al., 2013). Да корпоративна безбједност није искључиво подручје дјеловања 
у приватном сектору потврђује и Brooks (2012: 2). Он указује на проблем непостојања сагласности око одређења појма корпоративне безбједности и указује на пријеку потребу да се то уради. Он под појмом корпоративна безбједност сматра подручје дјеловања гдје се пружају услуге безбједности било у оквиру јавног или приватног сектора у сврху заштите пословања и материјалних добара.

Ако пођемо од схватања да подручје дјеловања корпоративне безбједности може бити и у јавном и у приватном сектору, морамо имати на уму да корпорације нису само економске организације ${ }^{3}$ за које се априори везује концепт корпоративне безбједности. Поред привредних субјеката то могу бити и универзитети, невладине организације, политичке партије цркве, итд.

\section{ПОСЛОВИ ПРИВАТНЕ И КОРПОРАТИВНЕ БЕЗБЈЕДНОСТИ И ОРГАНИЗАЦИОНИ ОБЛИЦИ ДЈЕЛОВАЬА}

У овом дијелу биће наведени послови који се најчешће врше у оквиру приватне безбједности и корпоративне безбједности. Када је ријеч о приватној безбједности, Kovacicih и Halibozek (2003) дефинишу као пружање услуга обезбјеђења, спровођења истрага или постављања алармних система и других напредних технолошких рјешења из области безбједности. Поред тога, компаније које пружају услуге безбједности на основу уговора могу бити глобалне компаније које пружају услуге анализе безбједносних ризика у појединим конфликтним подручјима у свијету, затим кризни менаџмет и др. Посебпо је значајно сагледати дјеловање приватних безбједносних компанија у кризним регионима. Оне у највећем броју случајева обављају послове логистике, оперативне подршке оружаним снагама, обуку, савјетовања из области одбране, послове спечавања криминалитета, те обавјештајне послове (Avant, 2012: 21). Ту су и приватне обавјештајне компаније које прикупљају и обрађују податке за потребе клијената, било да је ријеч о појединцима, компанијама или владама. Најчешће се ради о методу прикупљања и обраде обавјештајних података из отворених извора. Приватне обавјештајне компаније спроводе и друге послове попут сателитских снимања, електронског надзирања и праћења сигнала, извиђање и осматрање, спровођење психолошко-пропагандних активности и информатичког ратовања (Mikac, 2007: 91). Када је ријеч о приватној детективској дјелатно-

\footnotetext{
${ }^{3}$ Како би бар приближно могли одредити садржину појма корпоративне безбједности, морамо сагледати етимологију ријечи корпорација. У лексикону страних ријечи (Вујаклија, 1986). Корпорација долази од латинске ријечи lat. corporalis - више лица удружених у истом циљу којима је држава признала права правног лица, еснаф, друштво, удружење. У социолошком смилсу корпорација је друштвена организација, а сваку организацију сачињавају три основне компоненте, а то су људи, организациона структура и механизми управљања и одлучивања. Друштвне организације у социолошкој теорији (Kukić, 2004) дефинишу се се као групе људи организованих ради постизања одређених циљева, који су међусобно повезани на темељу формално утврђених улога и међусобних односа, сарадње и устројености.
} 
сти, као једној од дјелатности у оквиру приватне безбједности - најчешће се ради о прикупљању информација о пословним партнерима и компанијама, провјери података о лицима која конкуришу за одређена радна мјеста, затим о прикупљању информација и доказа у вези са злоупотребом ауторских права (Вејновић, et al., 2008) спровођење тзв. брачних истрага, односно утврђивања ванбрачних веза, проналажење несталих лица, послови пратње и присмотре дјеце ради утврђивања девијантних понашања, прикупљање доказа за потребе парничног или кривичног поступка, уручивање судских налога и других докумената, истраге унутар предузећа поводом отуђивања имовине, утврђивање захтјева за накнаду штете, праћење имовинског стања појединих лица, итд. Приватне казнене установе су такође једне од дјелатности које је држава пренијела у надлежност приватним компанијама. Тренд увођења приватних казнених установа је у порасту првенствено у САД, Великој Британији, Аустралији, Јужној Африци, али и у појединим европским земљама. Основни узрок настанка приватних казнених установа јесте значајан пораст затворске популације и немогућности да држава адекватно одговори насталим потребама. Приватизација казнених установа има предности и недостатке и отвара бројна етичка питања, попут: „да ли држава смије препустити извршавање кривичних санкција недржавним субјектима и да ли се тиме доводи у питање ресоцијализација лица на уштрб профита (Кесић, 2009: 98).“

Nalla и Morash (Nalla \& Morash 2002: 13) послове корпоративне безбједности сврставају у шест категорија: обезбјеђење лица, контрола улаза, заштита имовине, истраге, менаџмент ризика и „друго“. Brooks (2012) je радио истраживање у Аустралији и дошао до резултата да се послови корпоративне безбједности у првом реду односе на сигурносне технологије попут ИТ мрежа, видео надзор, контроле улаза, заштитне противпровалне системе, менаџмент ризика, управљање континуитетом пословања, физичко обезбјеђење, обезбјеђење личности, индустријска безбједност. Тек у другу категорију Brooks сврстава послове сповођења истрага, заштиту од пожара, заштиту на раду или обавјештајни рад у пословању. То нам указује да доминантни послови свакако зависе од карактеристика сваког друштва, његове економске развијености и специфичних захтјева тржишта.

Lippert и сарадници (Lippert et al., 2013: 216) наводе дјелокруг послова корпоративне безбједности на примјеру органа локалне управе у Канади. Ради се о пословима постављања и мониторинга видео надзора, патролна дјелатност, рјешавање ситуација непримјереног понашања, надзор над запосленим, спровођење истрага, контрола приступа, заштита имовине, обезбјеђење догађаја, обезбјеђење личности, спровођење тестова провјере сигурносних система и уочавања слабости, затим едукација запослених у циљу повећања безбједносне културе и поштовања безбједносних процедуpa. Даље, Lippert и сарадници (2013) послове корпоративне безбједности сврставају у двије категорије по критеријуму комплексности. Прва категорија je engl. physical (заштита лица, контрола улаза и заштита имовине), 
дакле послови који по овим ауторима захтијевају нижи ниво сложености. Друга категорије je engl. knowledge тј. послови који захтијевају комплекснија знања (истраге и менаџмент ризика). По овој подјели могли би сврстати само физичко обезбјеђење као посао нижег нивоа сложености, а све остале као послове који захтијевају комплексна знања. Класификацију послова корпоративне безбједности по Lippert-u и сарадницима потребно је критички преиспитати. Послови физичког обезбјеђења могу да захтијевају специјалистичка знања, у зависности од нивоа заштите објекта или лица која се штите. У тим случајевима се врши квалитетна селекција кадра, обезбјеђује висок ниво обуке, користе се савремена техничка опрема и ИТ технологије. Ти послови често захтијевају посебне вјештине (engl. skills) које се стичу обуком, далеко више него теоријска знања. Имајући у виду, била би адекватнија подјела послова на вјештине и знања (engl. skills і knowledge), него како то Lippert и сарадници наводе. Из наведеног можемо закључити да се послови у приватној или корпоративној безбједности не уклапају у стереотипно мишљење да се ради о ниско квалификованим пословима и ти послови често захтијевају висок ниво обучености и специјалистичка знања.

Из наведеног се може видјети широк спектар послова који се обављају у оквиру концепта корпоративне безбједности. Они се могу класификовати у категорије по њиховој сродности: 1) физичка безбједност 2) техничка безбједност 3) информациона безбједност 4) истраге 5) консалтинг 6) управљање кризама 7) обавјештајни послови.

Што се тиче организационих облика дјеловања у оквиру приватне безбједности то могу бити агенције за заштиту лица и имовине, затим унутрашње службе у оквиру приватних компанија, приватни истражитељи/ детективи или детективске канцеларије, консултантске фирме из области безбједности, приватне војне компаније, приватне обавјештајне компаније, приватне казнене установе, мигрантски и азилантски центри.

Када је ријеч о корпоративној безбједности, корпорације имају посебна одјељења за обављање послова корпоративне безбједности, а запослени у тим одјељењима су радници те компаније. Са друге стране, корпорација, било да посједује посеб̆о одјељење за корпоративну безбједност или не, може у циљу остваривања својих корпоративних интереса кориситити услуге по уговору од других субјеката који на тржишту пружају услуге безбједности.

\section{КОМПАРАТИВНА АНАЛИЗА КОНЦЕПТА ПРИВАТНЕ И КОРПОРАТИВНЕ БЕЗБЈЕДНОСТИ}

Lippert и сарадници (Lippert et. al., 2013) су понудили типологију корпоративне безбједности и на тај начин дали допринос њеном концептуалном одређењу. Типологија се састоји из пет димензија корпоративне безбједности: 1) јавни или приватни статус 2) врста послова 3) надзор 4) engl. source тј. да ли се ради о одјељењима у оквиру компаније или о услугама на осно- 
ву уговора 5) сертификација, обука и селекција кадра. Међутим, потребна су даља емпиријска истраживања у другачијем културном, економском и политичком контексту како би се оцијенила њена епистемолошка и практична вриједност. Предложену типологију користимо као аналитички оквир за компарацију корпоративне и приватне безбједности. Свака од пет димензија из типологије упоређивана је и анализирана. Прво су приказани резултати истраживања Lippert-a и сарадника по наведеној типологији, затим је типологија, односно тај аналитички оквир кориштен за анализу приватне безбједности. На кају је извршено упоређивање приватне и корпоративне безбједности како би се сагледало у којим димензијама типологије постоје преклапања и сличности, а у којима разлике. На основу таквог приступа добићемо издиференцирани приказ концептуалних сличности и разлика приватне безбједности и корпоративне безбједности. На основу компаративне анализе може се закључити сљедеће:

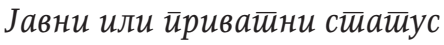

Статус агенција или појединаца које пружају услуге безбједности на основу уговора (приватна безбједност) увијек је приватни. Корпорације могу бити у јавном, мјешовитом или приватном власништву. Примјера ради, одјељења корпоративне безбједности, ако узмемо појам корпорације у ширем смислу, јесу органи локалне самоуправе, владине институције, велики привредни системи у државном или мјешовитом власништву. У том контексту корпоративна безбједност у потпуности не испуњава услов да се третира као приватна безбједност јер постоје статусно-правне разлике у смислу јавног а не искључиво приватног статуса, односно власништва.

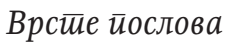

Према типологији (Lippert et al., 2013), у корпоративној безбједности присутна је „мјешавина“ послова које они категоришу по нивоу сложености на „физичке“ (engl. phisical) и „послове који захтијевају комплекснија знања" (engl. knowledge). То све зависи од саме корпорације која се штити и нивоа пријетњи и ризика са једне стране, и спремности менаџмента да развија одјељење безбједности у оквиру одређене компаније. Послови и у корпоративној безбједности и приватној безбједности различитог су нивоа сложености. У оквиру оба посматрана модела присутно је значајно преклапање послова. То су послови физичко техничке заштите, спровођење истрага, превенција криминалитета, кризни менаџмент, ИТ безбједност, обавјештајни послови итд. Чак постоји и сличност у врсти послова када се ради о кориштењу услуга приватних војних компанија које су ангажоване у конфликтним подручјима. Корпорације које послују у том окружењу ангажују приватне војне компаније за послове блиске заштите лица, пратње конвоја, обезбјеђења пословних објеката и инфраструктуре. Разлика је што се приватне војне компаније ангажују на пословима обављања борбених задатака, док се ти послови по правилу не врше у оквиру корпоративне безбједности. 


\section{Hag3op}

Трећа димензија безбједности наведене типологије односи се на надзор. Дакле, питање је ко врши надзор над овим дјелатностима. Значајне разлике у овом сегменту типологије не постоје између приватне и корпоративне безбједности. И једни и други морају пословати у складу са законом и другим прописима чију имплементацију контролишу државни органи, почевши од испуњавања услова за рад, лиценцирања особља, па надаље. Међутим, поред државе надзор над овим дјелатностима могу да обављају и професионална удружења, за примјер можемо навести АСИС у САД (American Society for Industrial Security), или рецимо Комору приватних детектива у Словенији, Мађарској итд. На одређени начин и тржиште врши надзор над њиховом дјелатношћу, исто као што је случај са надзором јавности када је јавна безбједност у питању. Пошто је приватна безбједност намијењена тржишту услуга, свакако да тржиште има значајан утицај на пословање субјеката који пружају услуге приватне безбједности. У литератури се наводе и друге неконвенционалне форме надзора када је ријеч о корпоративној безбједности, а које се односе на кривичну и грађанску одговорност менаџера безбједности. То исто важи и за менаџере у приватној безбједности (Lippert et al., 2013).

\section{Да ли се раяи о одјељењима у оквиру комйаније или о услуїама на основу уі̄овора (engl. source)}

У литератури поједини аутори (Kovacicih \& Halibozek, 2003) праве разлику између приватне и кропоративне безбједности првенствено на основу критеријума пружања услуга безбједности на основу уговора, што одговара приватној безбједности (engl. contract/outsource). Дакле, ријеч је о ангажовању приватних агенција за послове безбједности. Када се ради о корпоративној безбједности, мисли се на посебна одјељења за безбједност у оквиру компаније (engl. in-house/insource) чији радници су запослени у тој компанији. Ако пођемо од ширег одређења да се ради о свим активностима у циљу заштите компаније, компанија може ангажовати агенцију по основу уговора за одређене послове безбједности. Дакле, могућа су оба модалитета. Кључна разлика између приватне и корпоративне безбједности у овој димензији типологије је та што су послови приватне безбједности увијек намијењени тржишту у циљу стицања профита. Са друге стране, корпоративна безбједност штити интересе компаније и своје услуге не нуди на тржишту, али на том истом тржишту може да купује услуге безбједности како би интереси компаније били што боље заштићени.

\section{Серииификаиија, обука и селекиија каярова}

У литератури се наводи да особље ангажовано на пословима корпоративне безбједности у правилу има виши ниво образовања и степен обучености у односу на особље запослено у агенцијама за заштиту лица и објеката које пружају услуге безбједности на основу уговора (Lippert et al., 2013: 214). 
Примјер за то је АСИС (American Society for Industrial Security) аганција која нуди професионалне сертификате и обуку што је стандард за минимум квалификација за менаџере корпоративне безбједности. Такође, треба навести чињеницу да се често дешава да искусни и обучени професионалци прелазе из државних агенција за спровођење закона на послове корпоративне безбједности (Nalla \& Morash, 2002) и на друге послове у приватном сектору безбједности. Особље које ради у приватним агенцијама за обезбјеђење често је синоним за слабо плаћене послове и слабо обучене раднике обезбјеђења за разлику од особља које ради у одјељењима за безбједност у корпорацијама и који често похађају специјалистичке тренинге. Lippert и сарадници у својој типологији наглашавају управо ову разлику између корпоративне безбједности и оних који пружају услуге на основу уговора (contract guard security), односно приватне безбједности. Међутим, такво мишљење се мора критички преиспитати с обзиром да се у оквиру приватне безбједности врше различити послови, укључујћи и оне које захтијевају високе квалификације и стручна знања. Такве тврдње нису поткријепљене резултатима истраживања.

\section{ЗАКЉУЧАК}

Појам приватна безбједност и корпоративна безбједност често се користе као синоними. Циљ овог рада је био да се анализирају евентуалне концептуалне сличности и разлике између приватне безбједности и корпоративне безбједности. На основу прегледа доступне литературе може се закључити да постоји евидентан недостатак радова о теоријско-концептуалним питањима у вези са анализираним појмовима. Можемо рећи да поред бројних радова, посебно оних које третирају тематику приватне безбједности, недостаје општеприхваћен теоријски оквир за концептуализацију како приватне тако и корпоративне безбједности. У раду су наведена нека теоријска схватања у вези са овим појмовима. Пошли смо од претпоставке да приватна безбједност и корпоративна безбједност нису синоними и да је ријеч о два концепта који имају одређене заједничке карактериситике. Приватна безбједност и корпоративна безбједност су сродни појмови који имају значајне заједничке карактеристике (lat. genus proximum), али и специфичности што их чине различитим једно од другог (lat. differentia specifica). Како би наведену претпоставку потврдили или одбацили, извршили смо компаративну анализу између наведених појмова. У ту сврху, као аналитички оквир кориштена је типологија корпоративне безбједности Lipperta и сарадника (Lippert et al., 2013). Типологија се састоји из пет димензија: 1) јавни или приватни статус 2) врста послова 3) надзор 4) engl. source тј. да ли се ради о одјељењима у оквиру компаније или о услугама на основу уговора 5) сертификација, обука и селекција кадра. Тих пет димензија кориштено је и за анализу приватне безбједности и корпоративне безбједности. На основу компаративне анализе дошли смо до сљедећих кључних закључака: разлике 
између приватне и корпоративне безбједности су у елементу 1) (јавни или приватни статус) и елементу 4) (engl. source тj. да ли се ради о одјељењима у оквиру компаније или о услугама на основу уговора). Можемо закључити да корпоративна безбједност у потпуности не испуњава услов да се третира као приватна безбједност јер постоје статусно правне различитости у смислу јавног а не искључиво приватног статуса, односно власништва. Поред тога, послови приватне безбједности су увијек намијењени тржишту у циљу стицања профита, што није случај са корпоративном безбједности. Копоративна безбједност штити интересе компаније и своје услуге не нуди на тржишту, али на том истом тржишту може да купује услуге безбједности како би интереси компаније били што боље заштићени. Корпоративна безбједност је увијек везана уз корпоративни идентитет и то је њено специфично обиљежје што нужно не мора бити карактеристика дјелатности приватне безбједности. У осталим димензијама безбједности из типологије постоје значајна преклапања и нема битних разлика.

На основу компаративне анализе може се закључити да приватна безбједност и корпоративна безбједност јесу сродни, али су и концептуално различити појмови. Идентификоване разлике између приватне и корпоративне безбједности су значајне и због њих анализиране појмове не можемо посматрати на исти начин.

\section{ЛИТЕРАТУРА}

Abrahamsen, R., \& Williams, M. C. (2010). Security beyond the state: Private security in international politics. New York. Cambridge University Press.

Avant, D. (2012). Mercenaries. The Wiley-Blackwell Encyclopedia of Globalization.

Brooks, D. J. (2012). Corporate Security: Using knowledge construction to define a practising body of knowledge. Asian Journal of Criminology, 8(2), 1-13

Bruneau, T. (2011): Patriots for Profit - Contractors and the Military in U.S. National Security; Stanford. Stanford University Press.

Cunningham, W. C., \& Taylor, T. H. (1985). Private security and police in America: The Hallcrest report. Portland, OR: Chancellor Press.

De Waard, J. (1999). The private security industry in international perspective. European journal on criminal policy and research, 7(2), 143-174.

66 Duningan, M. (2011): Victory for Hire - Private Security Companies' Impact on Military Effectiveness; Stanford. Stanford University Press.

Halibozek, E., \& Kovacich, G. L. (2003). The manager's handbook for corporate security: establishing and managing a successful assets protection program. Butterworth-Heinemann. 
John E.E. (2005): Conceptualizing the Private Police. Utah law rewiew, 2, 573-617.

Johnston L. (1991). Privatisation and police function: from "new police" to "new policing" -in. Reiner R. and Cross M. (ed.): Beyond Law Order: Criminal Justice Policy and Politics in the 1990s, Basingstoke, Macmillian, pp. 1840.

Jones, T., \& Newburn, T. (1998). Private security and public policing. Clarendon Press.

Kakalik, J. S., \& Wildhorn, S. (1971). The Private Police Industry: Findings and Recommendationes (5 volume Rand report for the US Department of Justice), Santa Monica, Rand Corporation.

Кесић, 3. (2009). Приватни сектор у контроли криминалитета. Београд: Досије Студио.

Kinsey, C. (2006). Corporate soldiers and international security: The rise of private military companies. Routledge.

Кукић, С. (2004). Социологија: теорије друштвене структуре. Sarajevo Publishing.

Leander, A. (2005). The power to construct international security: On the significance of private military companies. Millennium, 33(3), 803-825.

Lippert, R. K., Walby, K., \& Steckle, R. (2013). Multiplicities of corporate security: Identifying emerging types, trends and issues. Security journal, 26(3), 206-221.

Loader I. (2000). Plural policing and democratic governance. Social and Legal Studies 9, 323-345.

Menz, G. (2011). Neo-liberalism, privatization and the outsourcing of migration management: a five-country comparison. Competition \& Change, 15(2), 116-135.

Микац, Р. (2007). Феномен „приватних војних организација”: незаобилазне компоненте у сукобима 21. стољећа. Полемос: часопис за интердисциплинарна истраживања рата и мира, 10(20), 85-107.

Nalla, M.K. and Morash, M.A. (2002). Assessing the scope of corporate security: Common practices and relationships with other business functions. Security Journal 15(3), 7-19.

Nemeth, C. P. (2018). Private security: An introduction to Principles and Practice. CRC Press Taylor \& Francis Group.

Печујлић, М. (2002). Глобализација: два лика света. Београд. Гутенбергова галаксија.

Sarre, R., \& Prenzler, T. (2005). The law of private security in Australia. Pyrmont, Thomson Lawbook. 
Shearing, C. D., \& Stenning, P. C. (1981). Modern private security: its growth and implications. Crime and justice, 3, 193-245.

Shearing, C. D., \& Stenning, P. C. (1983). Private security: implications for social control. Social problems, 30(5), 493-506.

South N. (1994). Privatizing policing in the European Market. European Sociological Rewiew, 10(3), 219-231.

South, N. (1988). Policing for profit: The private security sector. Sage.

Stenning P. C. and Shearing C. D. (1980). The quiet revolution - The nature, development and general legal implications of private policing in Canada, Criminal Law Quarterly, 22, 220-248

Stiglic, E. J. (2004). Proturečnosti globalizacije. Beograd: SBM-h.

Van Steden, R. (2007). Privatizing Policing - Describing and Explaining the Growth of Private Security. Den Haag: BJu Legal Publishers.

Walby, K., \& Lippert, R. K. (2014). Introduction: Governing Every Person, Place, and Thing-Critical Studies of Corporate Security. In Corporate Security in the 21st Century (pp. 1-13). London: Palgrave Macmillan.

Weiss, R. P. (2014). Corporate security at Ford Motor Company: from the great war to the cold war. In Corporate Security in the 21st Century (pp. 17-38). London: Palgrave Macmillan.

Вебер, М. (1976). Привреда и друштво. Београд: Просвета.

Вејновић, Д., Тривуновић, Ј., Матијевић, М., Ђокић, П., Вртовец, З., Лалић, В., Шикман, М., Перко, Ј., Ђукић С. (2008). Детективска дјелатност теоријски и практични аспекти по стандардима Европске уније. Бања Лука: Дефендологија центар за безбједносна, социолошка и криминолошка истраживања.

Vejnović, D., Lalić, V., Šikman, M. (2010). Private Security in Bosnia and Herzegovina. In: Cordner, G., Cordner, A., Das, D. (Eds). Urbanization, Policing, and Security - Global Perspectives. (389-402). New York: Taylor \& Francis Group,

Вујаклија, М. (1986). Лексикон страних речи и израза. Београд: БИГз.

Рад примљен: 01. 03. 2019. 